\title{
開水路キャビティー流れの乱流構造 に関する研究
}

\author{
禰津家久 1 - 山本義暢 2 \\ 1正会員 工博 京都大学大学院教授 環境地球工学専攻 (广606-8501 京都市左京区吉田本町) \\ 2学生員 京都大学大学院生 工学研究科環境地球工学専攻
}

\begin{abstract}
開水路キャビティー流れは, 剥離せん断首の発達, 組織渦の発生・発達・崩壊, あるいは逆流域, 死 水域の存在といった複雑な乱流場を形成する. 本研究ではこのようなキャビティー流れに対し, フルー ド数・レイノルズ数およびキャビティーのアスペクト比を系統的に変化させ, レーザ流速計を用いて高 精度に測定した. その実験結果により乱流棈造が特徴的に変化した 2 ケスに対して, 非定常数值シミュ レーションの有力な手法である Large Eddy Simulation(LES), また可視化手法として近年有力視されてい るParticle Image Velocimetry(PIV)を用いてこれらの組織構造について検討し, キャビティー流れに対する 2つのパラメータの影響および組織構造との関保について考察を行った.
\end{abstract}

Key Words : cavity flow, turbulence structure, mean velocity, coherent structures, LDA, LES, PIV, numerical calculation, open-channels

\section{1.はじめに}

河川法の改正に伴い従来の河川機能である治 水・利水機能に加えて新たに環境機能が加わり, 河 川においてもコンクリート三面張りの直線水路だ けでなく植生, 複断面といった多様性が求められ ている. 特に, トレンチ, ワンドに見られる「瀬 と淵」を有する流れは, 流送土砂制御や流量制御の 目的に加えて, 生態系保全にも役に立つというこ とで多自然型河川工法の一環として設置されるよ うになり，その設計・施工にあたっては水理学 的・流体力学的解明が必要不可欠になっている.

Knisely \& Rockwell ${ }^{1)}$ は, 上・下流端に段落ち, 段 上がりの 2 つの側壁のあるキャビティー流れにお いて 1 次元LDA(Laser Doppler Anemometer)を用い た乱流計測とともに水素気泡法による組織渦の可 視化を行った. その結果, 下流衝突端のない通常 の段落ち流れと比較して乱れ強度が50\%から80\% 低減することおよび，この現象は下流端からかな り上流側の領域でも起こること, また, キャビ ティー上流端から発生する剥離渦が下流端に衝突
する位置は規則的に変化することを指摘するとと もに, 流れの 3 次元性についても考察している.

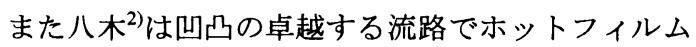
流速計を用いた点計測実験とともに, 染料注入法 を用いて可視化実験を行い，キャビティー界面で の流速変動は顕著なピーク周波数をもち，この界 面不安定波においては自由せん断層の場合と同様 に, 平行・非粘性の線形安定性理論が成立している ことを示した.このような非定常性, 3 次元性, 非等方性を有するキャビティー流れにおいては時 間平均諸量だけでなくその組織構造の解明が本質 的に重要となる.

一方，1970年代に発見された乱流のバースティ ング現象をMoin \& $\mathrm{Kim}^{3}$ が数值的にほぼ再現するこ とに成功したことで，一躍注目されるようになっ たLarge Eddy Simulation(LES)は, この種の組織乱 流構造の計算には画期的な手法である. 藤田ら ${ }^{4)}$, 5) はキャビティー流れに対しLESおよびPIV(Particle Image Velocimetry)を用いて解析し, その結果, せ ん断層内においては運動量と渦度に対し凍結乱流 の仮定がほぼ成立するが, 移流速度は平均流速の 


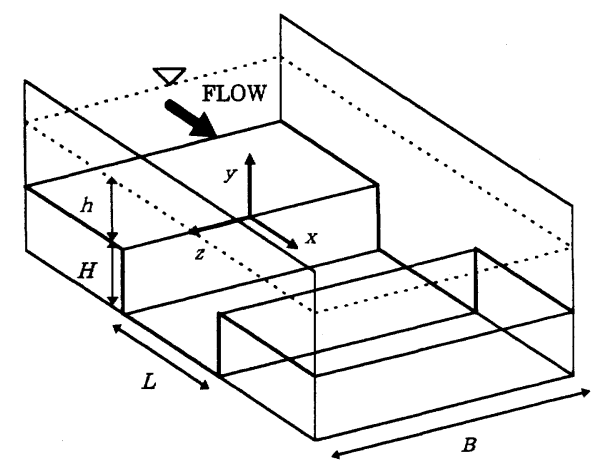

图-1 キャビティー形状と座標系

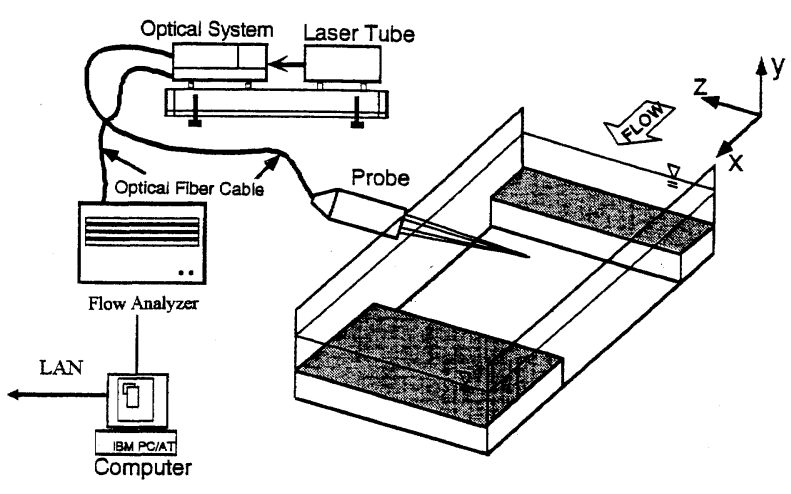

图-2 実験装置(LDA)
表-1 水理条件

\begin{tabular}{|c|c|c|c|c|c|}
\hline CASE & $h(\mathrm{~mm})$ & $L(\mathrm{~mm})$ & $L / H$ & $F r$ & $\operatorname{Re}\left(\times 10^{4}\right)$ \\
\hline FR12V05 & 66 & 33 & 0.5 & 0.12 & 0.63 \\
\hline FR12V10 & 66 & 66 & 1.0 & 0.12 & 0.63 \\
\hline FR12V20 & 66 & 132 & 2.0 & 0.12 & 0.63 \\
\hline FR12V30 & 66 & 198 & 3.0 & 0.12 & 0.63 \\
\hline FR12V50 & 66 & 330 & 5.0 & 0.12 & 0.63 \\
\hline FR12V70 & 66 & 462 & 7.0 & 0.12 & 0.63 \\
\hline FR20V30 & 66 & 198 & 3.0 & 0.20 & 1.06 \\
\hline FR20V50 & 66 & 330 & 5.0 & 0.20 & 1.06 \\
\hline FR20V70 & 66 & 462 & 7.0 & 0.20 & 1.06 \\
\hline FR30V30 & 66 & 198 & 3.0 & 0.30 & 1.59 \\
\hline FR30V50 & 66 & 330 & 5.0 & 0.30 & 1.59 \\
\hline FR30V70 & 66 & 462 & 7.0 & 0.30 & 1.59 \\
\hline
\end{tabular}

60\%〜80\%程度であること, そしてキャビティー 内部では底面に近づくにつれて流れの3次元性が強 まることを明らかにした。

以上のようにキャビティー流れにおいて組織渦 構造については部分的には解明されつつあるが, アスペクト比 $(L / H$, ここにLはキャビティー長さ, Hはキャビティー高さを示す)やフルード数を系統 的に変化させて, キャビティー流れにおける平均 流速や乱流統計量の変化, さらにはそれらに組織 構造が与える影響を扱った研究は少ない。そこで 本研究では，まずフルード数及びレイノルズ数, そしてキャビティーのアスペクト比を系統的に変 化させてLDAによる乱流計測を行い時間平均諸量 への影響について考察を行い，さらにLES, PIVを 用いてキャビティー流れの非定常な組織構造に関 する総合的な考察を行うものである.

\section{2. 長時間平均されたキャビティー流れの 乱流榗造}

\section{（1）実験方法}

本実験で使用した水路は，長さ $10 \mathrm{~m}$, 幅 $40 \mathrm{~cm}$, 高さ $50 \mathrm{~cm}$ の可変勾配型循環式直線水路である. 水 路勾配については, 各ケースそれぞれ, キャビ ティー上流部で等流状態になるように設定した. この水路の上流から $5.5 \mathrm{~m}$ の位置に設けたキャビ ティー形状と座標系を図-1に示す，また図-2に瞬 間流速の測定に用いたレーザ流速計の計測システ ムを示す. 使用した流速計は4ビーム後方散乱型2 成分アルゴンイオンファイバーレーザ流速計 (DANTEC社製)で,この流速計は, レーザ光の ON/OFF, シフト光の位相制御, バイアス制御など, 計測時に必要なすべての設定がコンピュータ支援 で行われ，ドップラー信号が相関法によって処理 される.このようにして得られた計測データは, ドップラー信号により計算された粒子速度ととも にバーストの開始時間(散乱粒子の測定ボリューム 到着時間), バースト継続時間(散乱粒子の測定ボ リューム通過時間)などが記録され, ワークステー ションに転送された後, 流速変換, および基本乱 流統計量に関する統計処理が行われた. 測定断面 は, 水路中央部において, キャビティー内部では7 〜10断面, キャビティー上, 下流部においては4 5断面とし, 測点はキャビティー内部において1断 面あたり36点, キャビティー外部では18点とした. 測定時間はサンプリング率の悪い壁面および水面 付近では 120 秒, その他の領域では60秒とした。し 


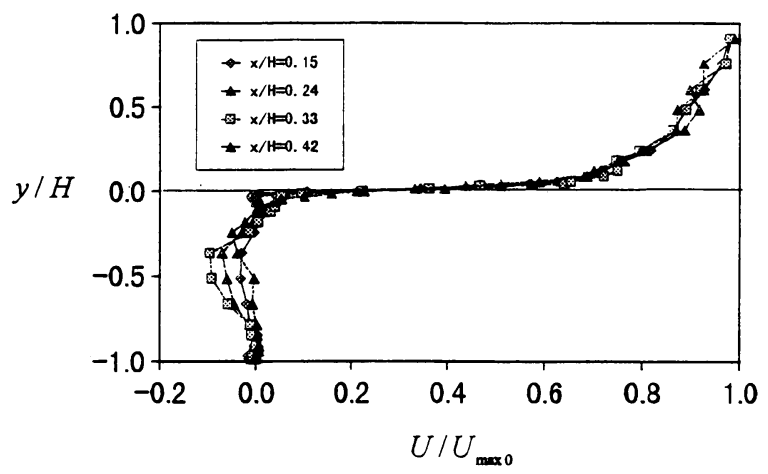

图-3 平均主流速分布 (ケース: FR12V05)
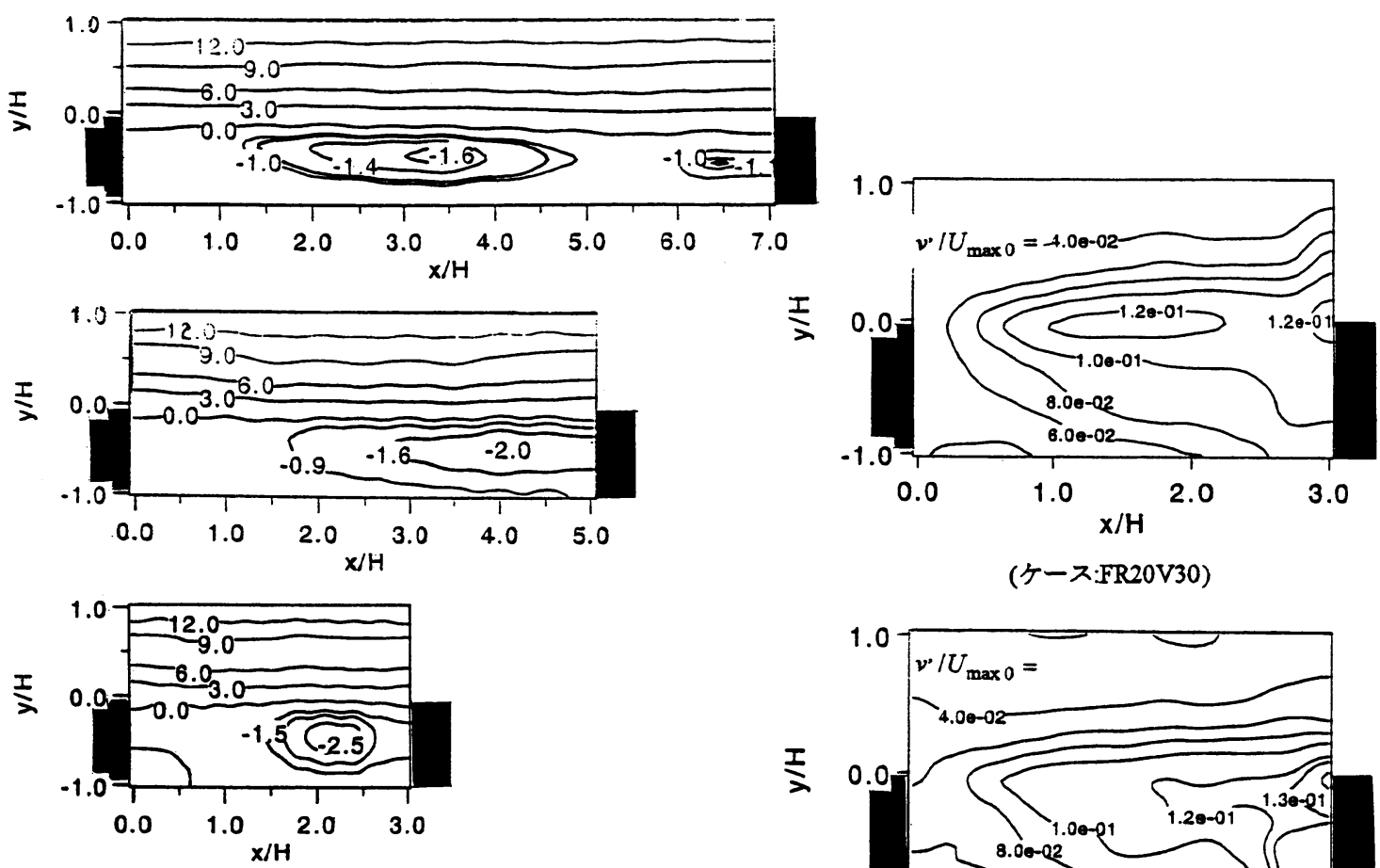

(ケース:FR20V30)

$$
\Psi(x, y)=\int_{-H}^{y} U(x, y) d y
$$

图-4 流線（上からケース :FR20V70，FR20V50，FR20V30）

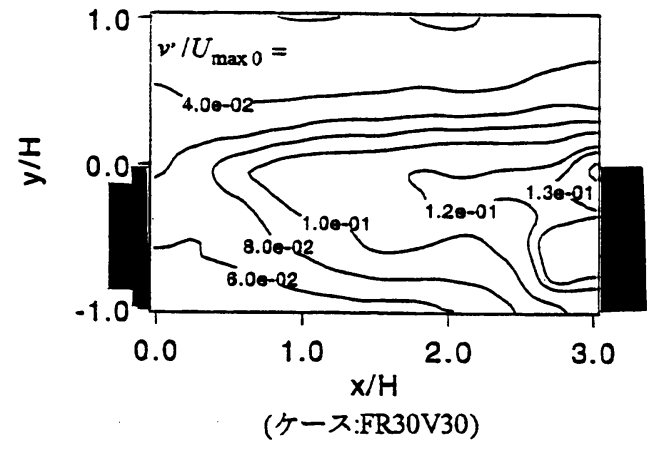

图-5 鉛直方向乱れ强度 $\boldsymbol{\nu}$ のコンター
たがって，サンプリング率は100～200Hzである.

表-1に本実験の水理条件を示す.ここにhは水深, $F r=U_{m} / \sqrt{g h}$ はフルード数, $U_{m}$ は初期断面の断面平 均流速, $g$ は重力加速度, $R e=U_{m} h / v$ はレイノルズ 数, $v$ は動粘性係数である. 本研究においてはフ ルード数及びレイノルズ数を3通り，アスペクト比 を3〜6通り変化させ, 開水路キャビティー流れに おけるフルード数およびレイノルズ数そして，ア スペクト比の影響を評価できる条件を選択した。

\section{（2）実験結果とその考宗}

開水路キャビティー流れにおいては, 主流と キャビティーの境界面より下の領域に死水域，ま た場合によっては循環渦, 再付着点が存在する. 図-3はFR12V05のキャビティー内部の主流速分布 を示したものである.アスペクト比の小さいこの ケースにおいてはキャビティー内部がほとんど死 水域になっている様子が伺える.图-4にはフルー 

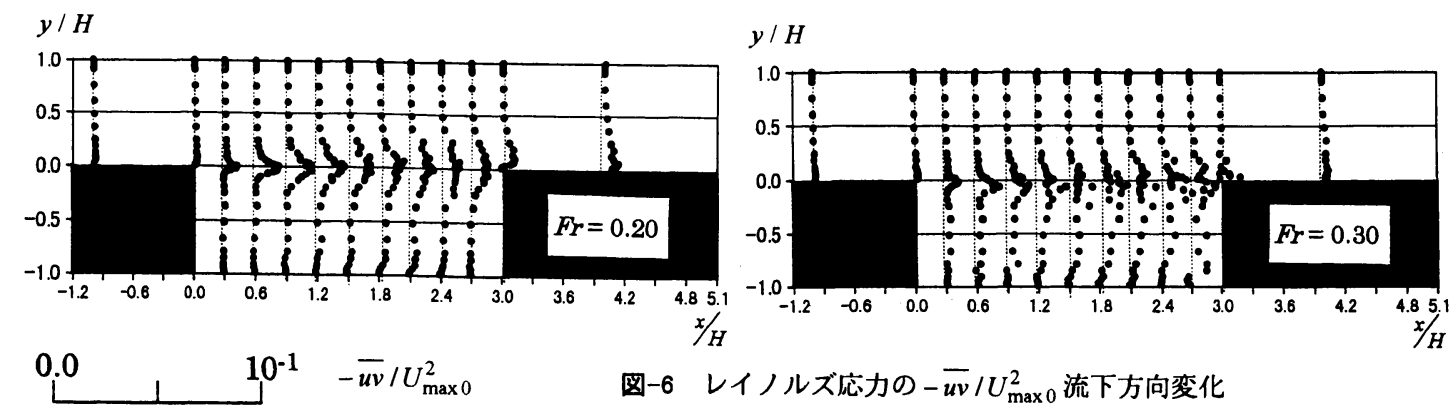

図-6 レイノルズ応力の $-\overline{u v} / U_{\max 0}^{2}$ 流下方向変化

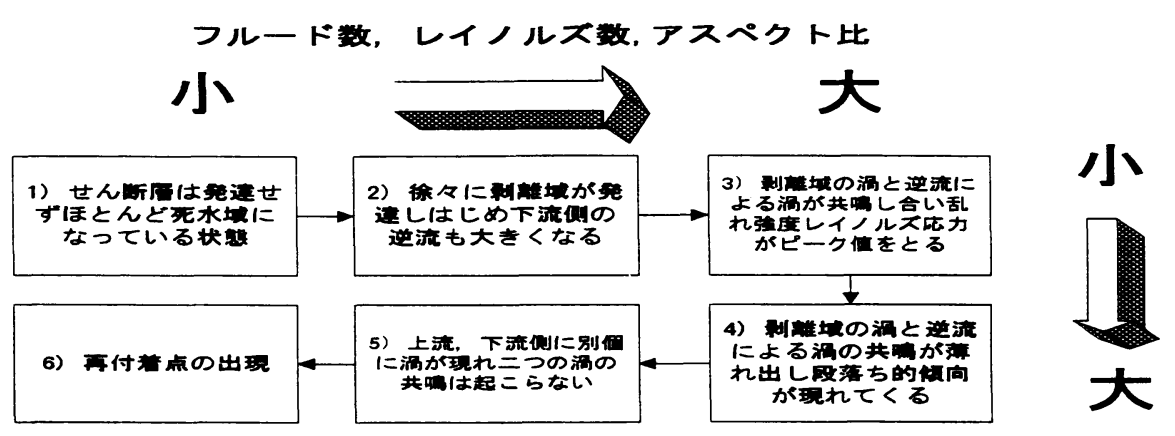

図-7 アスペクト比及びフルード数・レイノルズ数の変化に伴うキャビティー流れの変化

ド数 0.2 におけるキャビティー内部の流線を示す. $L / H=7.0$ のケースでは，下流端付近に新たな渦が出 現している．これは上流側の循環渦が，段落ちと して作用する上流壁に由来するものであると考え れば，下流端側の渦は衝突端として作用する下流 端壁によるものであり，この現象は藤田ら ${ }^{6)}$ の結果 にも見られる。一方， $L / H=3.0$ の場合は両方の渦が 合体している場合と考えられ，フルード数 $0.2 に お ~$ いてアスペクト比の変化に伴い乱れエネルギー, レイノルズ応力がキャビティー中央部付近におい てピーク值をとる. また， $L / H=5.0$ の場合は両者の 中間と考えられる.ところがフルード数 0.3 の場合 には图-5に示すように $L / H=3.0$ の場合において乱れ 強度が下流端付近でピーク值をとる.これは流速 差が大きいため主流がキャビティー内部に侵入し て流体混合の激しいせん断層が下降し段落ち流的 ${ }^{7}$ になり，その結果下流端での逆流による渦よりも 上流側の剥離域の循環渦の影響が強くなっている ものと考えられる.このことは, 图-6に示すレイ ノルズ応力の流下方向変化によってもキャビ ティー中央部より下流側でキャビティー内部の分 布形が膨らんでいる様子によって確認できる.ま た本研究では確認できなかったがこの場合さらに アスペクト比を大きくしていくと, 藤田ら ${ }^{6)}$ のよう に再付着点が現れるものと予測される. 以上のこ
とから水面変動の影響の少ないキャビティー流れ における乱流構造にはアスペクト比に加えてフ ルード数およびレイノルズ数(せん断層の流速差)も 効果的に作用するものと考えられる.

以上のことより水面変動による影響の少ない場 合のフルード数及びアスペクト比の変化に伴う キャビティー流れの変化をまとめると図ー7に示す ように，以下のようになる.

1) アスペクト比, フルード数およびレイノルズ 数が小さい場合にはキャビティー内部はほとん ど死水域になっており，流体混合はほとんど行 われない. (ケースFR12V05, FR12V10)

2）1)の状態からアスペクト比を大きくしていく と徐々にせん断層が発達し始め下流側の逆流も 大きくなって行く. (ケースFR12V20)

3) さらにアスペクト比を大きくしていくとキャ ビティー上流側の剥離域の渦と下流側の逆流の 渦が共鳴し合い, 水理条件一定のもとではこの 場合に乱れエネルギー，レイノルズ応力がピー ク値をとる. (ケースFR12V30，FR20V30)

4) 3)の状態からアスペクト比及びフルード数を 大きくしていくと，剥離域の渦と逆流による渦 の共鳴が薄れ出し，せん断層がキャビティ一内 部へ侵入し段落ち的傾向が現れ始める.（ケー スFR12V50, FR12V70, FR20V50, FR30V30, 


\section{FR30V50)}

5) アスペクト比の增加に伴い今度は上流側, 下 流側に別個に渦が現れ，この2つの渦の共鳴は 起こらない. (FR20V70, FR30V70)

6) この後, アスペクト比, フルード数およびレ イノルズ数の増加に伴い再付着点が出現するこ とが予測される.

\section{3. キャビティー流れの組織搆造}

LDAによって得られた結果のうち，全ケース中 で乱れエネルギー，レイノルズ応力が最大值を とったFR12V30のケースと，それと対照的に，乱 れエネルギー, レイノルズ応力が小さかった FR12V10の2ケースに対してLESによる数值計算, PIVによる可視化実験を行い，特に特徵的な組織構 造が見られたFR12V30のキャビティー流れの乱流 構造と組織構造との関連性について考察する.

\section{（1） LESによる数值解析法}

\section{a) 基磷方程式}

1方程式モデルのLESの基礎方程式は以下のよう に表せる ${ }^{8)}$

$$
\begin{gathered}
\frac{\partial \overline{u_{i}}}{\partial x_{i}}=0 \\
\frac{\partial \overline{u_{i}}}{\partial t}+\overline{u_{i}} \frac{\partial \overline{u_{j}}}{\partial x_{j}}=\Omega_{i}-\frac{\partial}{\partial x_{i}}\left\{\frac{\bar{p}}{\rho}+\frac{2}{3} K_{G}\right\} \\
+v \frac{\partial}{\partial x_{j}}\left(\frac{\partial \overline{u_{i}}}{\partial x_{j}}+\frac{\partial \overline{u_{j}}}{\partial x_{i}}\right)-\frac{\partial \tau_{i j}}{\partial x_{j}} \\
\frac{\partial K_{G}}{\partial t}+\bar{u}_{j} \frac{\partial K_{G}}{\partial x_{j}}=2 v_{T} \bar{D}^{2}-C_{\varepsilon} \frac{K_{G}^{2 / 3}}{\Delta} \\
+\frac{\partial}{\partial x_{j}}\left\{\left(\frac{v_{T}}{\sigma_{k}}+v\right) \frac{\partial K_{G}}{\partial x_{j}}\right\}
\end{gathered}
$$

$\Omega_{i}=(g \sin \theta,-g \cos \theta, 0), \quad K_{G}=\frac{1}{2} \overline{u_{i}^{\prime} u_{i}^{\prime}}, \quad v_{T}=C_{V} \Delta K_{G}^{1 / 2}$,

$$
\begin{gathered}
\tau_{i j}=-v_{T}\left(\frac{\partial \overline{u_{i}}}{\partial x_{j}}+\frac{\partial \overline{u_{j}}}{\partial x_{i}}\right), \quad \Delta=\left(\Delta_{1} \Delta_{2} \Delta_{3}\right)^{1 / 3}, \bar{D}=\left(\overline{D_{i j}} \overline{D_{i j}}\right)^{1 / 2} \\
\text { ただし, } D_{i j}=\frac{1}{2}\left(\frac{\partial u_{i}}{\partial x_{j}}+\frac{\partial u_{j}}{\partial x_{i}}\right), \\
C_{v}=0.05, \quad \sigma_{k}=0.5, \quad C_{\varepsilon}=1.0
\end{gathered}
$$

ここで $u_{i}$ は $i$ 方向の速度成分 $(i=1,2,3), x_{1}(x)$ は
流下方向, $x_{2}(y)$ は $x_{1}(x)$ に垂直上向き方向, $x_{3}(z)$ は横断方向, バー一は空間平均を施した值, プラ イム'は空間平均からのずれ， $\Delta$ はフィルター幅， $p$ は圧力, $\rho$ は密度, $\quad \sin \theta$ は河床勾配をそれぞれ 示し, 繰り返し添え字はEinsteinの縮約規約に従う ものとする.

式 (1) は連続式, 式 (2) は運動方程式, 式 (3) は subgrid scaleの乱流エネルギー $K_{G}$ の輸送方程式で ある。

\section{b）数值解析手法}

本研究では, 差分スキームは時間に対して2次精 度のAdams-Bashforth法，空間に対しては2次精度の 中心差分(コンシステントスキーム吕，10) )を用いた。 差分アルゴリズムとしてSMAC法を使用し，速度 ポテンシャルの計算は共役残差法により解いた. メッシュ系はスタガード格子を適用し，格子分割 は $x, y ， z$ 方向についてそれぞれFR12V10のケース は99×70×50，FR12V30の場合は $165 \times 70 \times 50$ とし た. 従って, キャビティー上流部における摩擦速 度による内部変数表示で各格子間隔は $\Delta x^{+} \approx 6.2-$ 12.4, $\Delta y^{+} \approx 3.1-17.2, \Delta z^{+} \approx 12.4$ である. 初期条 件はFR12V30においては $k-\varepsilon$ モデルの2次元計算 結果に一様乱数を加えた流れ場を与え, FR12V10 においてはFR12V30の計算結果の一部を初期条件 に用いた，境界条件は流入，流出面において主流， 横断方向に周期境界条件，壁面においてはno-slip 条件，水面においては鉛直方向の流速を 0 ，その他 に対称条件を用いた。そして，計算開始から20万 ステップ経過後, 流れが定常に達しているのを確 認したので，その後の無次元時間で約 118 (無次元 時間 $T=R / U_{\max 0}=1$ は実時間では約 0.5 秒である, ここに $U_{\max 0}$ は初期断面の最大時間平均流速， $R$ は 初期断面の径深である)の間のグリッドスケールに おける瞬間值およびアンサンブル平均值を本研究 における実験值と比較する諸量とした．また，本 研究では主流, 横断方向について周期境界条件を 用いているが $x, y, z$ 方向の乱れ成分の空間的な相関 をとり相関値が0に達していることを確認している ので周期境界条件による組織構造および平均諸量 一の影響はほとんどないと考えられる，なお，流 下方向 $x$, これに垂直上向き方向 $y$, 横断方向 $z$ につ いてそれぞれ時間平均流速を $U, V, W$, レイノルズ 応力を- $\overline{u v}$, 乱れ強度の各成分を $u^{\prime}, v^{\prime}, w^{\prime}$, 乱流エネ ルギーを $k($ ただし，本研究では横断方向の流速は 測定しておらず，また高精度のLDA実測值と計算 結果を比較するのが目的であるため，便宜的に乱 れ強度 $\left(u^{\prime}, v^{\prime}\right)$ から “乱れエネルギー” $k$ を定義する， すなわち $\left.k=\left(u^{2}+v^{2}{ }^{2}\right) / 2\right)$, としそれぞれ初期断面 の最大流速 $U_{\max 0}$ で無次元化した. 


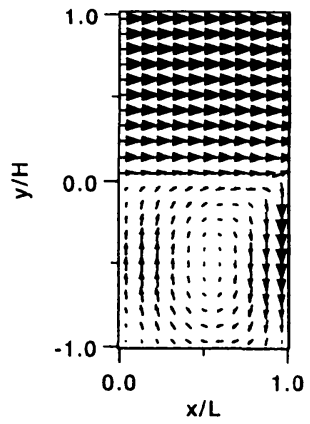

計算値 (ケース:FR12V10)

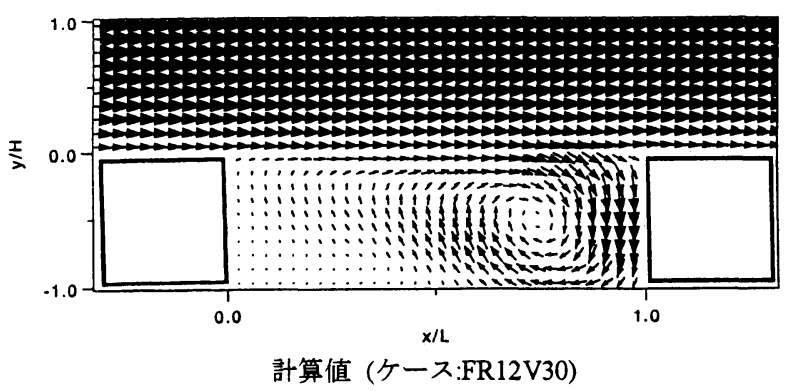

計算値 (ケース:FR12V30)

图-8 平均流速 $\left(U / U_{\max 0}, V / U_{\max 0}\right)$ のベクトル

(a) LES 計算値

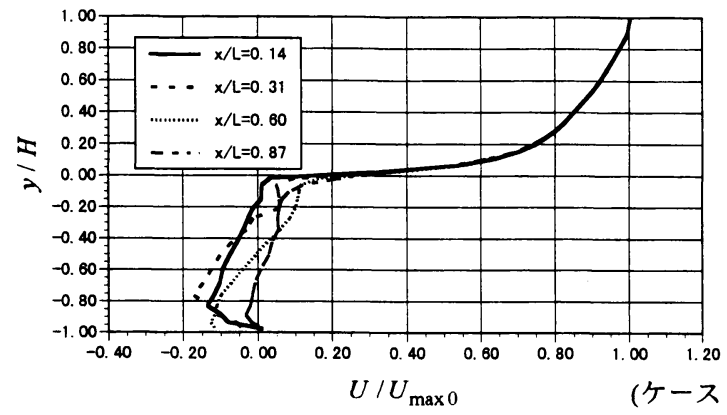

(a) LES 計算値

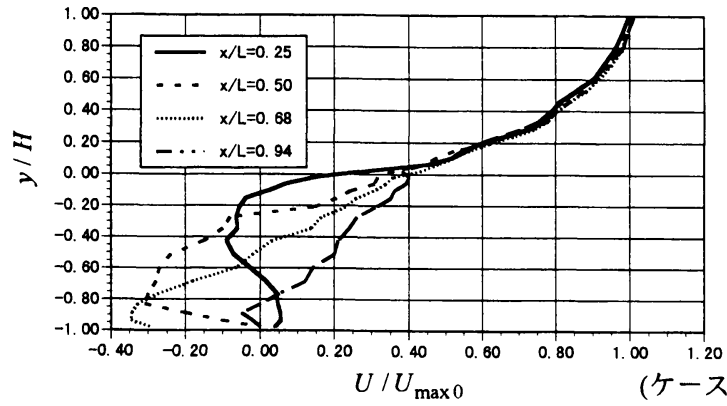

(b) LDA 実測値

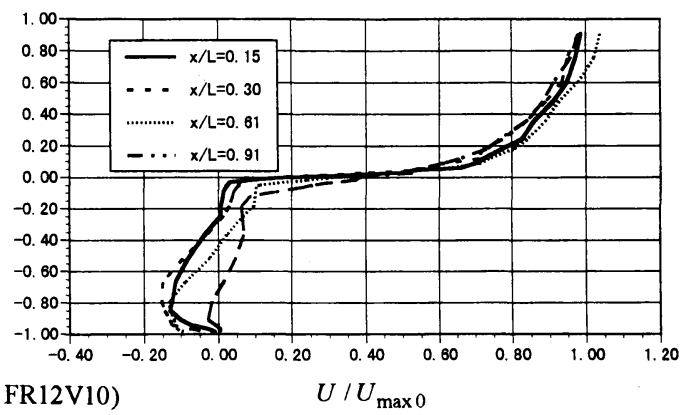

(b) LDA 実測值

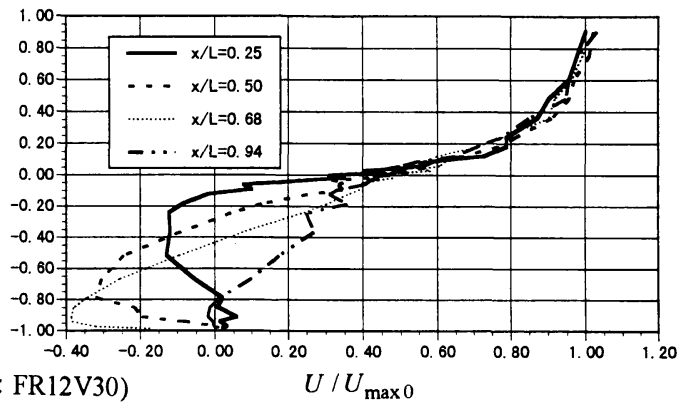

图-9 平均主流速の流下方向変化

\section{（2）PIVによる可視化实济方法}

本実験ではLDAで用いた水路と同様の水路にお いて, まず直径50 $\mu \mathrm{m}$, 比重 1.02 のナイロン12粒子 をトレーサー粒子としてアルコール液で十分にか くはんした後, 水中に一様に混入した. そしてア ルゴンイオンファイバーレーザよりシリンドリカ ルレンズを用いて厚さ約 $2 \mathrm{~mm}$ のレーザライトシー 卜(LLS)を水路上方から垂直にパルス的に照射して， 水路中央断面における約 $15 \mathrm{~cm} \times 20 \mathrm{~cm}$ の範囲を水路 側方からCCDカメラで撮影した。詳しいPIVシステ ムは文献11)を参照されたい。ここでの画像の1ピ クセルは約 $0.5 \times 0.5 \mathrm{~mm}$ である．測点はキャビ
ティー内部において $x$ 方向に30点, $y$ 方向に 30 点の 計900点とした. 撮影された画像は1/30秒間隔で光 ディスクに記録され，フレームメモリーボードを 介してPIV法によってコンピュータで処理され， LLS平面内の瞬時の多点速度情報を得た。

\section{（3）解析結果}

\section{a) 時間平均流速分布特性}

図-8は平均流速のベクトル図である. FR12V10, FR12V30ともキャビティー内部の組織渦の存在が 確認できるが, FR12V10の方はキャビティー内部 がほとんど死水域になっているのに対 LFR12V30 
(a) LES 計算値

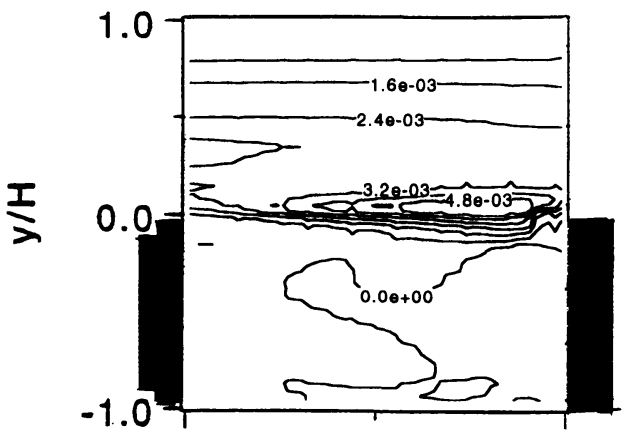

0.0

$x / L$

(a) LES 㖕算值

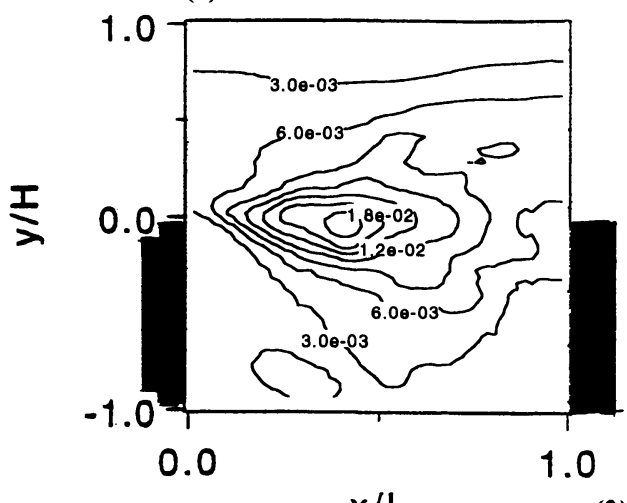

$x / L$

(a) ケース FRI2V10

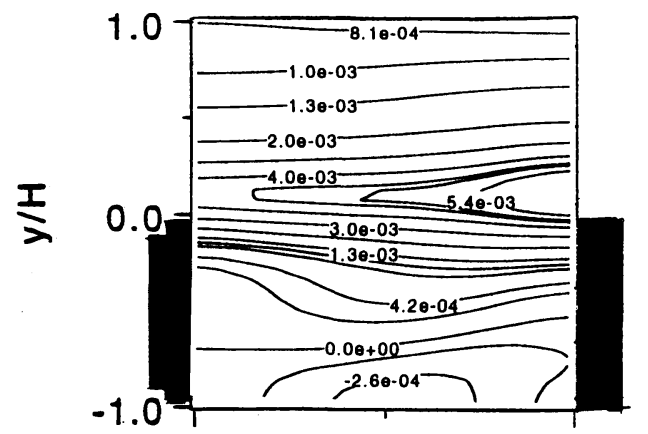

0.0
1.0
(1) ケース : FR12V10

(b) LDA 実測値

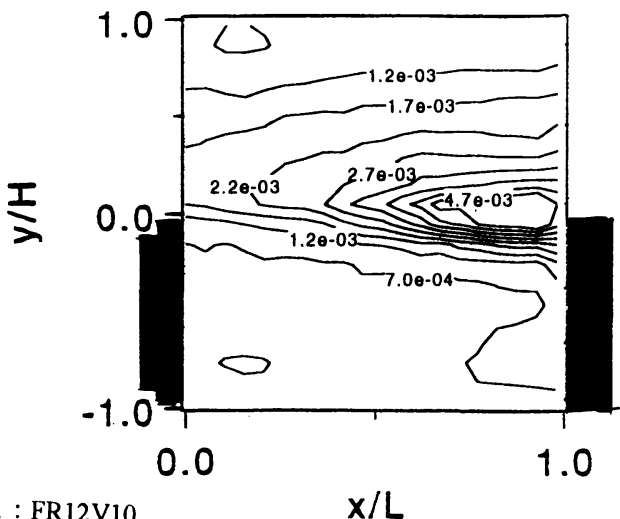

(b) LDA 実測値

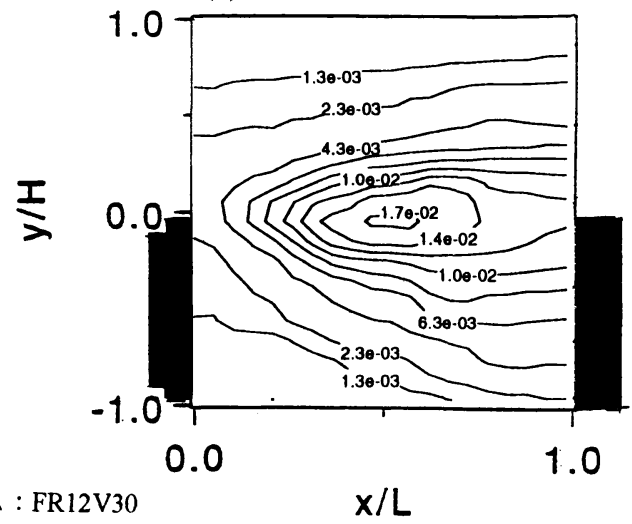

(b) ケース FR12V30

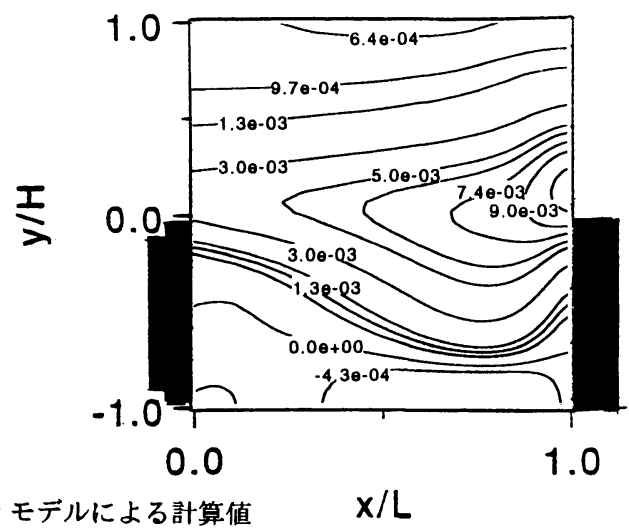

(3) 標準型 $k-\varepsilon$ モデルによる計算値

图-10 レイノルズ応力 $-\overline{u v} / U_{\max 0}^{2}$ のコンター

のケースではキャビティー界面において混合層の 広がりを示唆している，また図-9は，流下方向 $x$ 人 の流速分布の変化を示す図であり，FR12V30は FR12V10よりも逆流域がより下流に現れる点，ま たキャビティー内部においてはFR12V30の方が逆 流が強い傾向がLDAの実測值に見られる，LESに
よる計算値はLDAの実測値と極めて良好な一致を 示し，注目に値する.

\section{b) 乱れ統計量の分布特性}

图-10はレイノルズ応力アスペクト比の小さいFR12V10のケースでは， キャビティー界面の下流端付近でピーク值をとる 
(a) LES 計算値

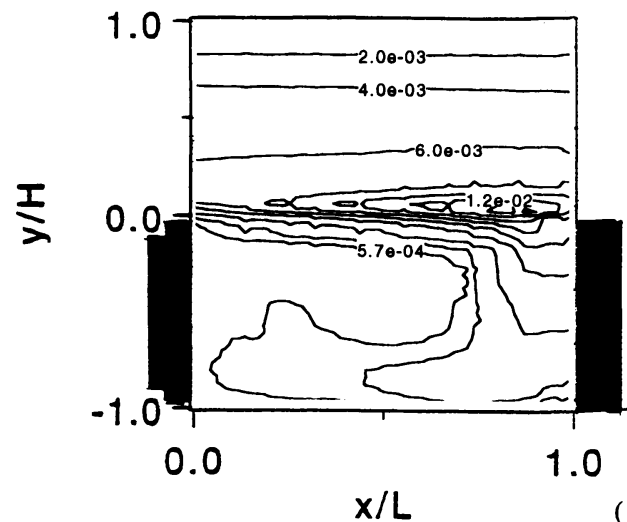

(a) LES 計算値

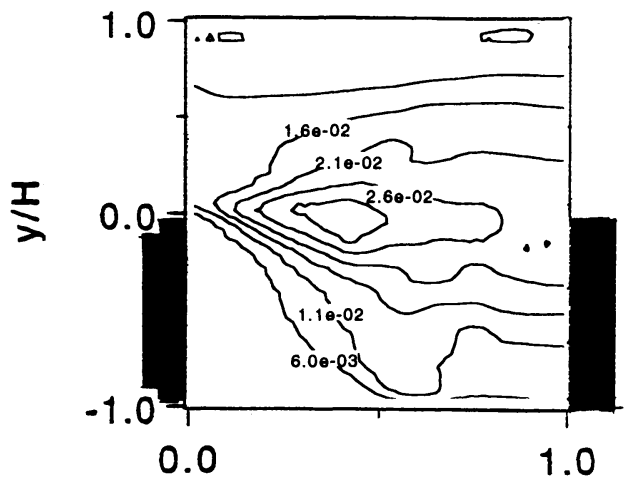

$\mathrm{X} / \mathrm{L}$ (b) LDA 実測値

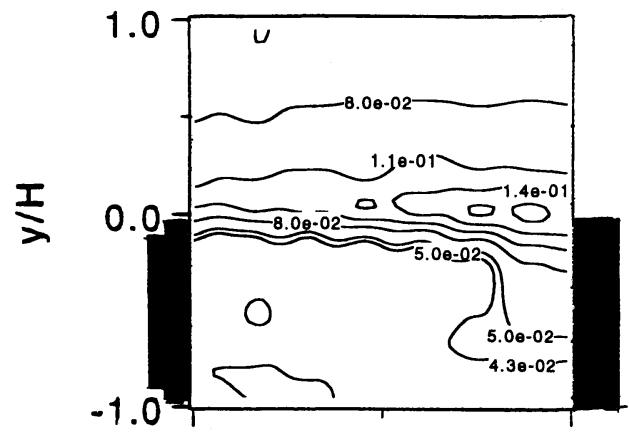

0.0

1.0

(1) ケース: FR12V10

$X / L$

(b) LDA 実湘値

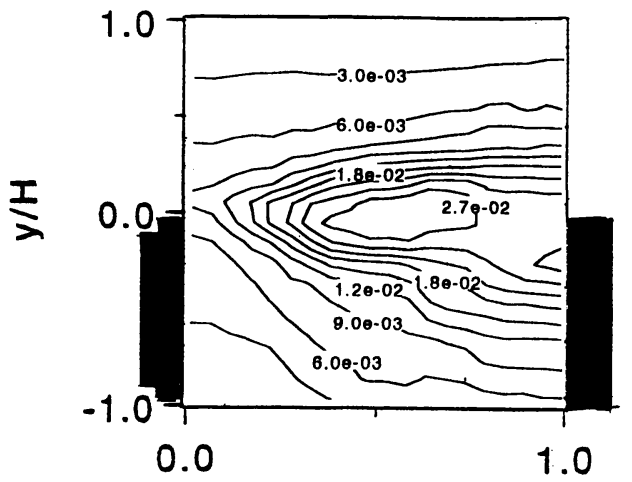

$x / L$

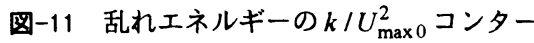

(a) $v^{\prime} / u^{\prime}$

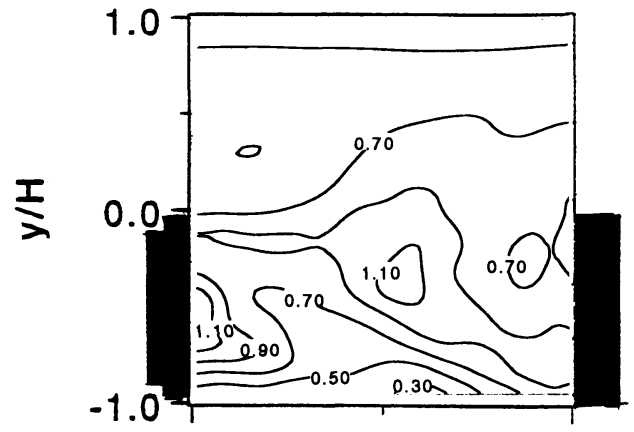

0.0
1.0 (b) $w^{\prime} / u^{\prime}$

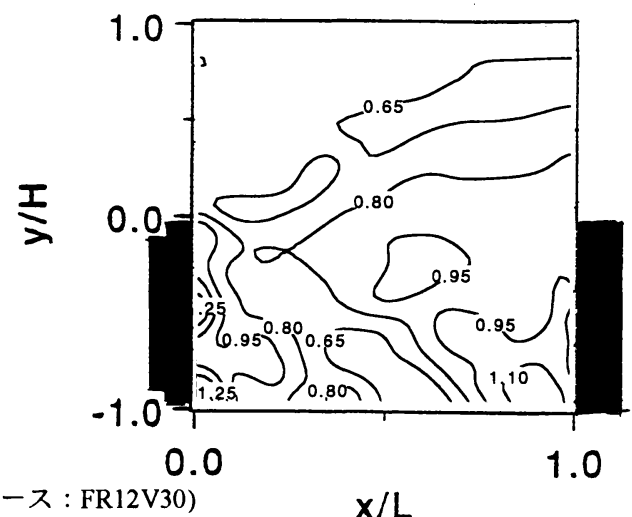

$x / L$

图-12 乱れ強度比 $v^{\prime} / u^{\prime}$ および $w^{\prime} / u^{\prime}$ の分布

傾向や流体混合がキャビティー界面近傍のみで行 われている傾向が定性的・定量的にLESで再現でき ているが，キャビティー下流端の底面付近で逆流 による影響を若干強く計算している。これは下流 端付近での格子の解像度が足りなかったためであ
ろうと思われる. ケースFR12V30においても同様 に，キャビティー上流端付近から混合層が広がり キャビティー中央付近でピーク值をとる点や界面 を中心として流下方向に扇状に広がっていく点な ど值，分布傾向ともにLESにより良好に再現できて 

$\tilde{\boldsymbol{u}} / U_{\max 0}$
(a) 計算値

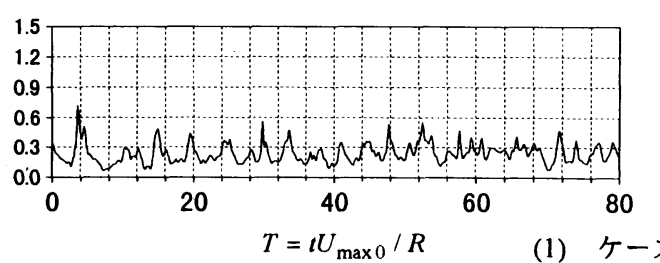

(1) ケース: FR12V10 (b) LDA 実測値

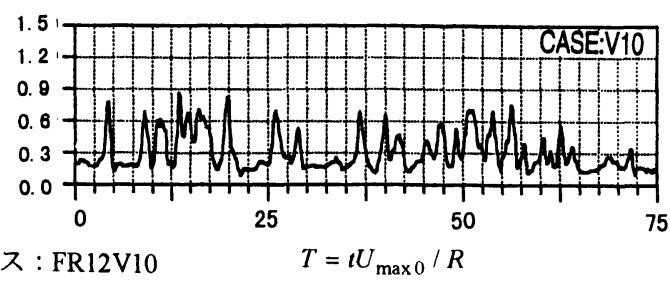

$\tilde{u} / U_{\max 0} \quad$ (a) 計算值

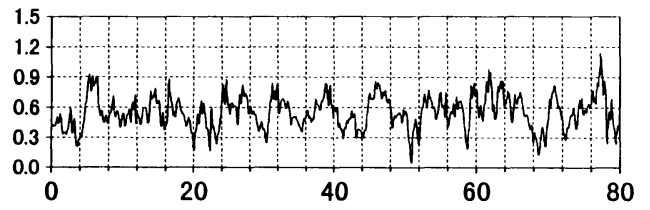

$\tilde{\boldsymbol{u}} / U_{\max 0} \quad$ (b) LDA 実測值

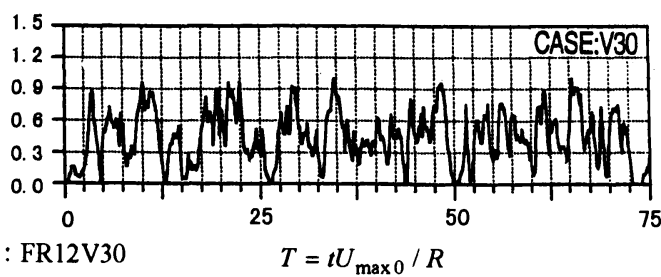

図-13 界面付近の主流速の時系列（～は瞬間値を示す）

(a) LES 計算値

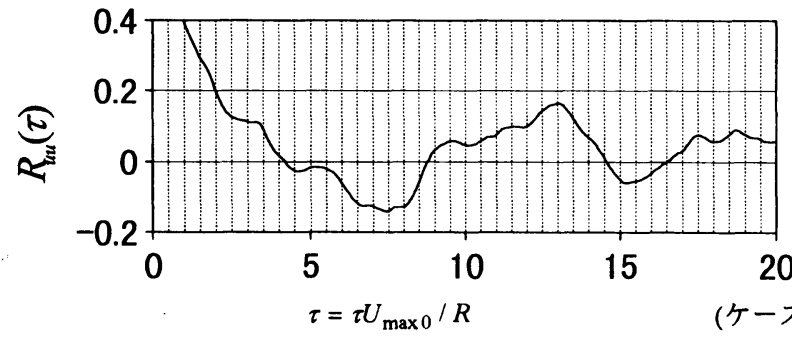

(b) LDA 実測値

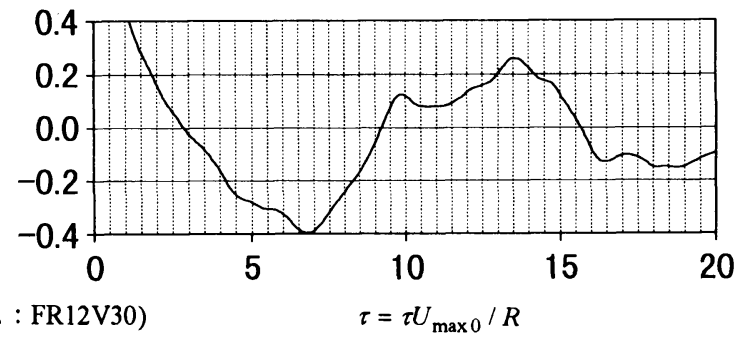

图-14 界面付近の変動主流速の自己相関係数

いる. また参考のために標準型の $k-\varepsilon$ モデルの2次 元計算結果も併記する.これにより標準型の. $k-\varepsilon$ モデルではキャビティーのアスペクト比の変化に よる乱流造の違いを再現できないことが分かる.

一般に標準型 $k-\varepsilon$ モデルでは剥離を伴う複雑乱流 には適用度が悪いことが再確認される。この原因 については, 今後LESデータベース等をもちいて乱 流統計量の輸送過程を調べ, より高次の応力モデ ル等と比較・検討する必要があると思われる.

図-11は乱れエネルギーのコンターである.これら もレイノルズ応力の分布特性と同様の傾向が伺え る.また図-12はFR12V30のケースにおける乱れ強 度比的 $/ u^{\prime} ， w^{\prime} / u^{\prime}$ である。これらよりキャビ ティー上流端付近及び底面付近に非等方性の強い 領域が見られる. 以上よりLESが開水路キャビ ティー流れにおいてキャビティー形状の違いによ る乱流構造の違いを良好に計算できることが分か
る.

\section{c）組機渦の発生・発達機權}

キャビティー流れにおいては混合層のせん断不 安定により不安定波が周期的に放出されることが よく知られている2). そこで図-13に界面付近の主 流速の時系列を示す. これにより界面付近では不 安定波が通過したときに大きく流速変動が生じる ことから，不安定波は必ずしも一定間隔で発生し ないことが分かる. またアスペクト比の違いによ りその変動が大きく異なり, アスペクト比の小さ いFR12V10の場合には不安定波が間欠的に通過す るのに対し，アスペクト比の大きいFR12V30の ケースでは断続的に不安定波が通過することが分 かる、いづれにせよLESによる計算値はLDAによ る実測値の傾向と良好に一致している.また図-14 はFR12V30のケースにおける変動主流速の自己相 関係数を示したものである. ラグタイム $\tau=10 \sim 15$ 


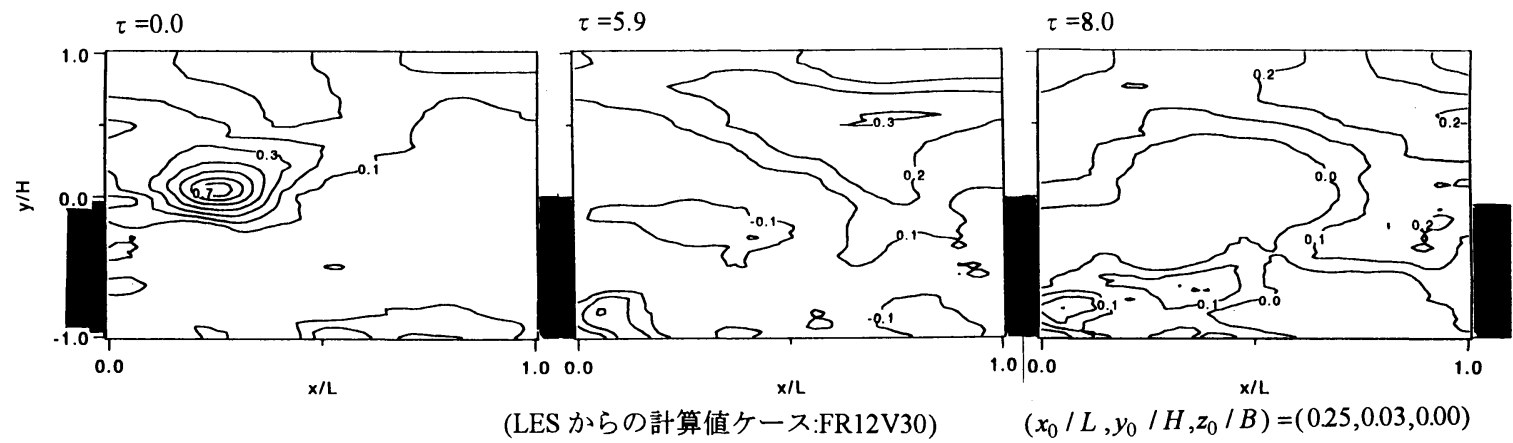

図-15 変動主流速の時空間相関俰数 $C_{u u}$ のコンター

(a)計算値 (LES) $\quad T=0.0$

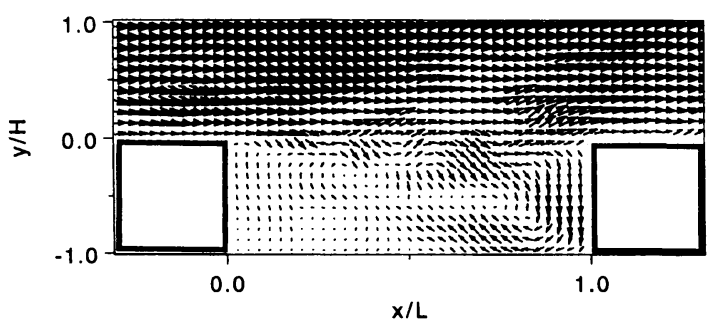

図-16 循環渦 (b) 実測値 (LDA) $\quad T=0.0$

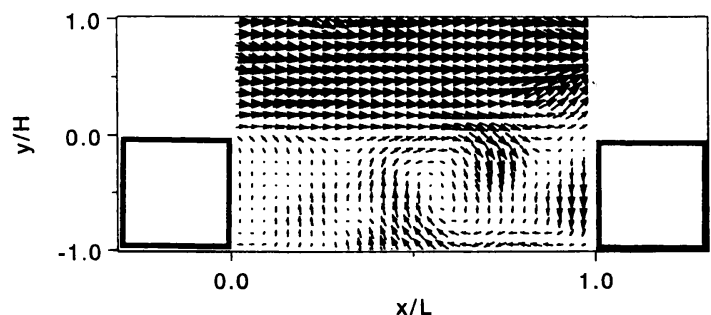

$\left(\tilde{u} / U_{\max 0}, \tilde{v} / U_{\max 0}\right)$ (a)計算値 (LES) $\quad T=3.13$

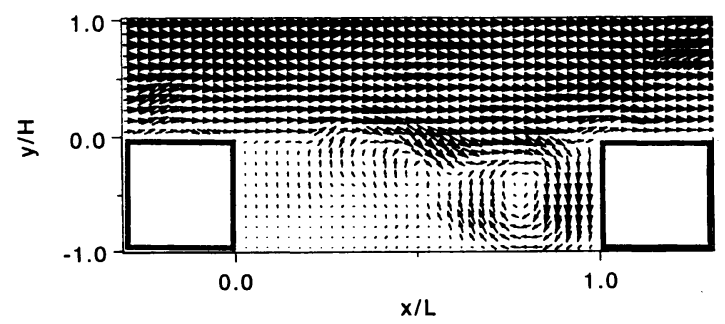

(b) 実測值 (LDA) $\quad T=6.65$

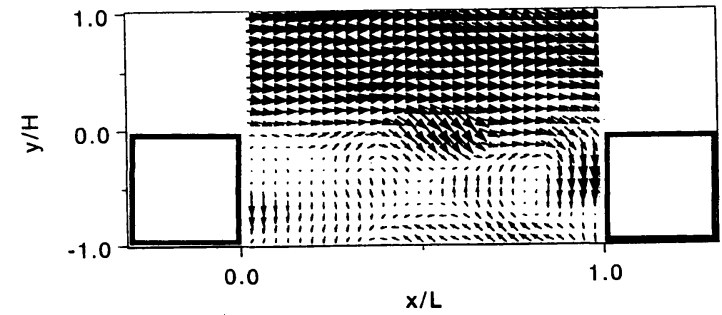

$\left(\tilde{u} / U_{\max 0}, \tilde{v} / U_{\max 0}\right)$
に高い相関が見られ，キャビティー上流部におけ る剥離渦の発生周期を示すものと考えられる. 図一 15はFR12V30のケースにおける, 以下の式(4)で表 される主流変動成分 $u$ の時空間相関係数 $C_{u u}$ のコン ターを示すものである.

$$
\begin{aligned}
& C_{u u}(\Delta x, \Delta y, \Delta z, \tau) \\
& =\frac{\overline{u\left(x_{0}, y_{0}, z_{0}, t\right) u\left(x_{0}+\Delta x, y_{0}+\Delta y, z_{0}+\Delta z, t+\tau\right)}}{u^{\prime}\left(x_{0}, y_{0}, z_{0}, t\right) u^{\prime}\left(x_{0}+\Delta x, y_{0}+\Delta y, z_{0}+\Delta z, t+\tau\right)}
\end{aligned}
$$

ここに, $\left(x_{0}, y_{0}, z_{0}\right)$ は固定点の座標， $\Delta x, \Delta y, \Delta z$ は
移動点座標の固定点に対する遅れ距離， $\tau$ は後れ 時間， $u^{\prime}$ は乱れ強度である。これによりキャビ ティー上流部での剥離渦がほぼ移流速度により下 流側へ流下し, キャビティー下流端において一部 はキャビティー内部へ潜り込み，一部はキャビ ティー外部へ放出されることが伺える.このよう にキャビティー流れにおいては混合層のせん断不 安定いわゆるK-H不安定による剥離渦が組織構造に 大きく関与することが示唆される.そこでキャビ ティーのアスペクト比の変化により乱れエネル 
(a)計算値 (LES) $\quad T=5.09$

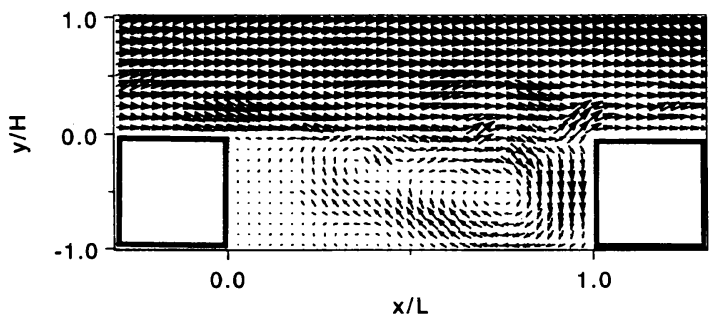

図-18循環渦のキャビティー下流端への衝突 (b) 実測値 (LDA) $\quad T=7.76$

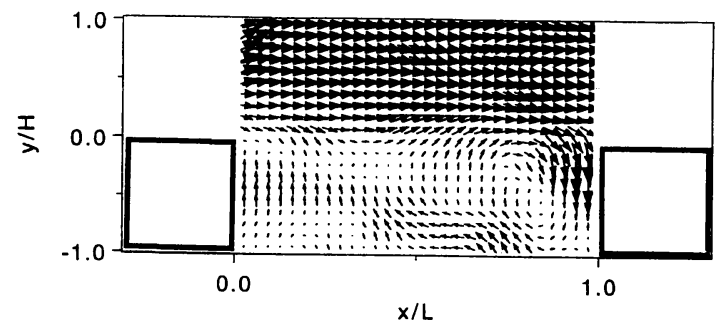

$\left(\tilde{u} / U_{\max 0}, \tilde{v} / U_{\max 0}\right)$ (a)計算値 (LES) $\quad T=13.71$

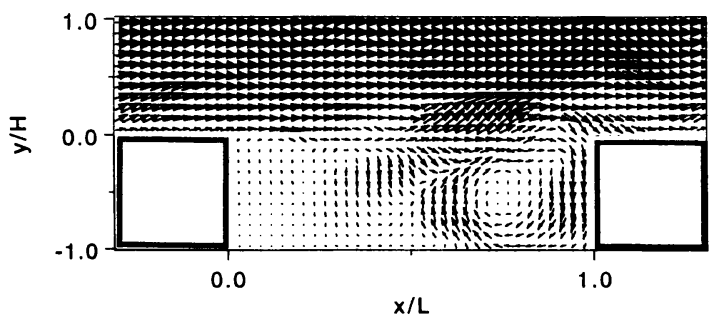

图-19 不安定波と循環渦の衝突 II (b) 実測值 (LDA) $\quad T=10.21$

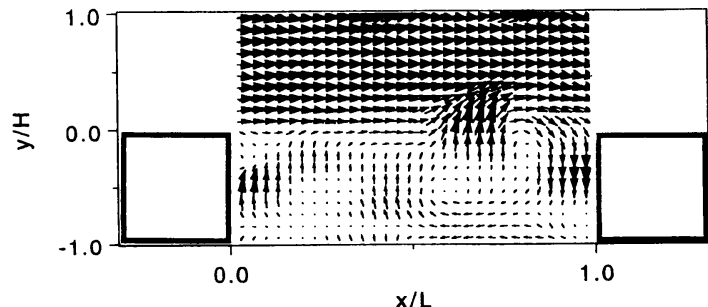

$\left(\tilde{u} / U_{\max 0}, \tilde{v} / U_{\max 0}\right)$ (a)計算値 (LES) $\quad T=15.43$

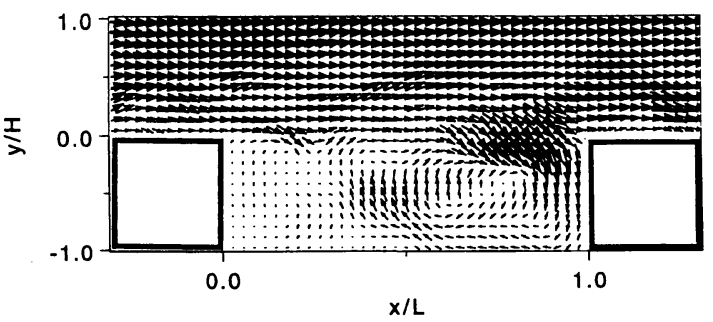

図-20キャビティー界面付近の流体の巻き込み (b) 実測值 (LDA) $\quad T=13.75$

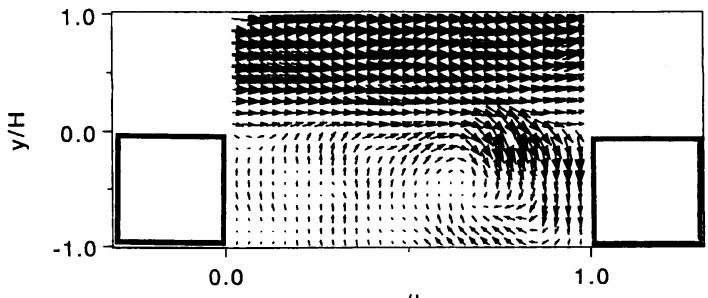

$x / L$

$\left(\tilde{u} / U_{\max 0}, \tilde{v} / U_{\max 0}\right)$
ギー, レイノルズ応力がピーク值をとるFR12V30 のケースについて瞬間流速のベクトルを詳細に検 討していくと，このケースにおける流れはキャビ ティー上流端で剥離した流れがロールアップする までの領域である線形領域と，ロールアップを起 こした後の非線形領域に分けられる. そして, そ の組織構造は, 混合層における不安定波(剥離渦)の 発生周期とキャビティー下流端の循環渦の大き さ・中心位置により, ある過程を何回も重複した り, 省略したりしながら反復しているが, 不安定 波の発生周期と下流端付近の大きな循環渦との関 係により以下のようなパターンを繰り返している ことがLESデータベースより判明した.すなおち，
(1) キャビティー下流端に存在する大きな循環 渦(図-16)に無次元時間4～15間隔で発生する不安定 波がキャビティー中央からやや上流側で衝突し(図 -17)この剥離渦を連行し大きな循環渦が下流端に 移動し一部はキャビティー外部に放出され，一部 はキャビティー内部に引き込まれる(図-18).

(2) またキャビティー下流端へ押しやられた循 環渦に次の剥離渦が流下し二つの渦がキャビ ティー中央部やや下流端側で衝突し(図-19)再び大 きな循環渦を形成する.

(3)さらにこの循環渦は，キャビティー界面付近 の流体を巻き込み(図-20), さらに大きな循環 渦を形成し(図-21)再び(1)に戻る. 
(a)計算值 (LES) $\quad T=17.27$

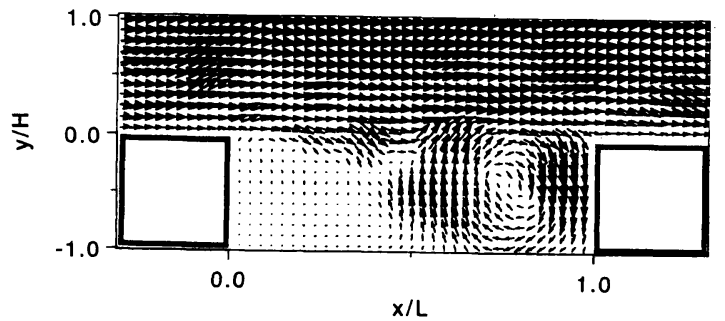

(b) 実測值 (LDA) $\quad T=16.85$

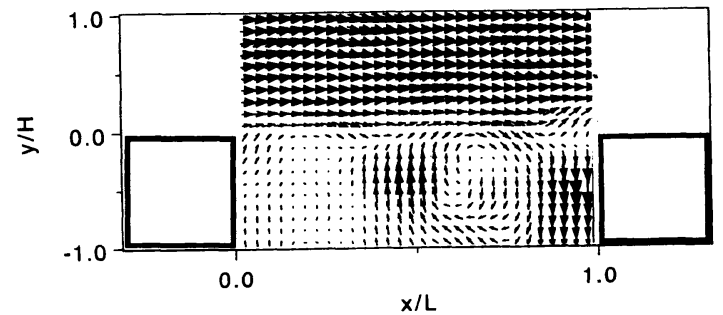

図-21 大きな循環渦の形成

$\left(\tilde{u} / U_{\max 0}, \tilde{v} / U_{\max 0}\right)$

このような過程は, Knisely \&Rockwell ${ }^{1)}$ の指摘す るように剥離渦が下流端に衝突する位置は規則的 に変化することと関連があると思われる，また， 同様の組織構造がPIVによる実験結果からも何える がその発生周期はやや異なっており，さらに詳細 に検討する必要がある.

\section{d）組機渦の乱流䟽計量に及ぼす影}

FR12V30のケースにおいてはレイノルズ応力及 び乱れエネルギーがキャビティー中央部において ピーク值をとるが、これは上記の過程により K-H不 安定波と下流端壁の存在により発生する循環渦が 衝突する中心部に相当する. また，そのことが不 安定波をさらに增強させることになる。つまりこ の現象はキャビティー下流端に潜り込んだ組織渦 と混合層におけるK-H不安定波との共鳴現象であり， 上流部と下流部に $2 つ$ 側壁を有するキャビティー 流れ特有の組織構造であると考えられる.

\section{4. 结的}

本研究においては, 開水路キャビティー流れに おいて, フルード数・レイノルズ数及びキャビ ティーのアスペクト比を系統的に変化させLDAに よる乱流計測を行い平均諸量への影響について考 察を行った．さらに，LES，PIVを用いてキャビ ティー流れの組織構造の乱流統計量への影響につ いて検討し以下のような結論が得られた.

（1）水面変動による影響の無視できる条件の下で はアスペクト比及びフルード数・レイノルズ数 の変化によりキャビティー流れにおける平均流 速, 乱流統計量の分布特性は空間的に大きく変 化する.

（2）LESはLDAによって得られた実測値と良好に
一致する.すなわち, 本研究のLESはキャビ ティー幅の変化による平均流速, 乱れエネル ギー, レイノルズ応力等の分布特性や值の変化 を定性的・定量的に良好に再現できる.

（3） キャビティー流れの組織構造についてLESと PIVの実測值は定量的にはややずれる傾向があ るものの定性的には良く一致する.

(4) LES，PIVの解析結果からキャビティーの幅 の変化により乱れエネルギー, レイノルズ応力 がピークをとるケースにおいては剥離渦の発生 周期と循環渦の大きさや中心位置との関連によ りいくつかの過程を反復していることが分かっ た.

（5）剥離渦と大きな循環渦が衝突するキャビ ティー中央部において，乱れエネルギーおよび レイノルズ応力がピーク值をとる現象と, この 組織構造は大きく関連している可能性があり, このような組織渦の相互作用をより詳細に検討 する必要がある.

（6）今後, よりフルード数が大きく, 水面変動の 激しい流れにおける，キャビティー流れの乱流 構造の変化についても検討し，キャビティー流 れを系統的に評価する必要があると思われる。

謝辞 : 本研究を行うにあたり, 京都大学大学院環 境地球工学専攻・平岡久司助手に多大なるご協力 とご助言を頂いた。ここに，謝意を表する．

\section{考考文献}

1) Knisely, C. and Rockwell, D. : Self-sustained lowfrequency components in an impinging shear layer, $J$. Fluid Mech., vol.16, pp.157-186, 1982.

2）八木俊策：凹凸流路における水質伝播に関する基 
礎的研究，京都大学学位論文, 1984.

3) Moin, P. and Kim, J. : Numerical Investigation of Turbulent Channel Flow, J. Fluid Mech. Vol. 118, pp. 341377, 1982.

4) 藤田一郎, 神田徽, 門脇正夫, 海津利幸：PIVによ るトレンチ内流れの乱流特性の解析, 第26回乱流 シンポジウム講演会論文集, pp.96-99, 1994.

5) 藤田一郎, 神田徹, 森田卓光：LESによる開水路 CAVITY内流れの乱流特性の解析, 第26回乱流シン ポジウム講演会論文集, pp.334-337, 1994.

6) 藤田一郎, 神田徹, 門脇正夫, 森田卓光 : 開水路 凹部流れのPIVおよびLESによる乱流解析, 土木学 会論文集，No. 539/II -35，pp. 79-88， 1996.

7) Nakagawa, H. and Nezu, I. : Experimental investigation on turbulent structure of backward-facing step flow in an open channel, J. Hydraulic Research, vol. 25, pp. 67-
88, 1987.

8) Horiuti, K. : Large eddy simulation of turbulent channel flow by one-equation modeling, pp.2855-2865, 1985 .

9) Kawamura, H. : Direct Numerical Simulation of Turbulence by Finite Difference Scheme, The Recent Developments in Turbulence Research, pp. 54-60, International Academic Publishers, 1995.

10）梶島岳夫：対流項の差分形式とその保存性, 日本 機械学会論文集(B編)，60-574，pp. 2058-2063， 1994.

11) Nezu, I. And Nakayama, T. : Space-time correlation structures of horizontal coherent vortices in compound open-channel by using particle-tracking velocimetry, $J$. Hydraulic Research, vol. 35, No. 2, pp. 191-208, 1997.

（1998. 3. 23受付）

\section{STUDY ON THE TURBULENT STRUCTURES IN CAVITY OPEN-CHANNEL FLOWS}

\section{Iehisa NEZU and Yoshinobu YAMAMOTO}

This paper describes turbulent structures in cavity open-channel flows. Turbulence measurements were conducted by making use of a two-component fiber-optic Laser Doppler Anemopmeter(LDA), where the Froude number, the Reynolds number and the aspect ratio of cavity shear layer changed. Next, Large Eddy Simulation(LES) and flow visualization by Particle Image Velocimetry(PIV) were carried out for two cases of experiments of which turbulent structures shows the characteristic behaviors. As the result, the effects of changes of Froude number, Reynolds number and the aspect ratio of the cavity shear layer, also the relationship of coherent structures were revealed and discussed. 